\title{
Thermogravimetry as a tool for measuring of fracturing fluid absorption in shales
}

\author{
Krzysztof Labus ${ }^{1} \cdot$ Małgorzata Labus ${ }^{1}$ (D)
}

Received: 13 October 2017 / Accepted: 4 March 2018/ Published online: 10 March 2018

(C) The Author(s) 2018. This article is an open access publication

\begin{abstract}
Water-based fracturing fluids are used for gas shale stimulations. The fluids are pumped under pressure into the well to create conductive fractures in hydrocarbon-bearing zones. The chemical additives vary depending on the geological and technical conditions of the well. One of the requirements of good fluid coherence is its low absorbency relative to the formation rock. Standard water absorption tests for rocks are usually performed on cubic samples $(50 \times 50 \times 50 \mathrm{~mm})$ soaked in water. In case of rocks which are drilled from the borehole, obtaining such large samples is very difficult; therefore, an attempt was made to determine the rock absorption on small samples, using the TG analysis. Thermogravimetric (TG/DTG) experiments were conducted in temperature range $40-300{ }^{\circ} \mathrm{C}$ in synthetic air environment. Shale rock samples were soaked in water and fracturing fluid. The absorption of the rocks is related to the shale's mineral composition, which was also determined by thermal analysis (TG/DSC).
\end{abstract}

Keywords Fracturing fluid $\cdot$ Shale $\cdot$ Absorption - Thermogravimetry

\section{Introduction}

Hydraulic fracturing is one of the most popular methods of stimulating hydrocarbons reservoirs in non-conventional formations [1]. Fracturing is used for enhancing the production of oil and gas from formations of very low permeability, i.e., tight gas, coal and shale gas deposits. The fluids are pumped under pressure into the well to create conductive fractures in hydrocarbon-bearing zones. The fracturing fluids used for gas shale stimulations consist primarily of water but also include a range of additives. The type and number of chemical additives are dependent on the conditions of the specific well being fractured. In case of water-based fracking fluids, the permeability damage in shale formation can be caused by swelling of clay minerals or by other physical and chemical mechanisms. As a result of uncontrolled hydration, caused by physicochemical interaction between fluid and shale or clay rocks, the crystal structure of minerals is disturbed.

Małgorzata Labus

malgorzata.labus@polsl.pl

1 Institute for Applied Geology, Silesian University of Technology, 2 Akademicka St., 44-100 Gliwice, Poland
One of the requirements of good fracturing fluid is its low absorption in the formation rock.

In the present study the TG/DSC method was used to study the composition of shale rocks, and TG method for absorption tests to examine the interaction of the specific shale samples and fracturing fluid. Standard water absorption tests for rocks are usually performed on cubic samples $(50 \times 50 \times 50 \mathrm{~mm})$ soaked in water. In case of rocks which are drilled from the borehole, obtaining such large samples is very difficult; therefore, an attempt was made to determine the rock absorption on small samples, using the TG analysis. This analytical method was also used by Corrêa and Nascimneto [2] for shale-fluid interactions, regarding drilling fluids influence on wellbore stability.

\section{Fluid absorption in shale}

Water absorption capacity is one of the basic physical properties of rocks. Water absorption tests are usually performed on dimensional stones which are used for building purposes [3]. 
The conventional absorption tests include stone sample cutting to usually cubic shape, as it was mentioned above. The samples are oven-dried and then weighed. In the next stage the dry sample is immersed in water for a specified period of time and then weighed again. The difference in mass (as a percentage) is the amount of water that penetrated the stone sample. It is worth mentioning here that the size and shape of the samples under examination are not strictly specified [4].

Measured absorption typically ranges from less than a per cent for granites and crystalline rocks up to 10-12 mass per cent for the more porous sedimentary rocks (like sandstones and limestones). Water absorption values of siltstones and mudstones are relatively large-of about $1-3 \%$ [5]. Water-absorbing rocks are formed from minerals that can hold water in their crystal structure or between grain boundaries. In case of shales and other clay-rich rocks, containing phyllosilicates, water absorption is often accompanied by a change in the crystal sizes because of their hydratation ease with which these minerals hydrate.

Aughenbaugh [6] stated that water absorption in shale decreases exponentially with time. In his experiment over $80 \%$ of total absorption took place after 5-6 days, and equilibrium was reached in 10-20 days. If no discontinuity or defect existed in shale structure, the depth of moisture absorption would be very shallow. In the laboratory tests the effective penetration depth is of about $6 \mathrm{~mm}$ [7]. Aughenbaugh [6] commented that rocks with bedding planes perpendicular to the exposed face absorbed $50 \%$ more water than ones with the bedding parallel to the free surface. The result is anisotropic expansion and shrinkage after capillary action and drying.

Several studies analysed the role of clay minerals on water imbibition capacity of shales [8, 9]. Imbibition is a process of absorbing a wetting phase into a porous rock. Spontaneous imbibition refers to the process of adsorption with no pressure driving of the phases into the rock. Some experimental investigations were also performed on shale imbibition capacity towards hydraulic fracturing fluids $[10,11]$. Currently, it is well known that the imbibition of fracturing fluids is mainly controlled by the capillary pressure, while the effects of clay absorption have not been studied thoroughly [10]. Because different mechanisms seem to be facilitating imbibition in the shale, there is not so far a verified answer for the geomechanisms behind those observations [11].

\section{Analytical methods}

Phase composition of the selected samples was determined with the use of XRD analysis. XRD measurements were taken with the use of powder diffractometer Bruker-AXS
Advance D8 (Germany) of $2 \Theta / \Theta$ geometry, equipped with linear semiconductor detector Lynxeye and energy-dispersive detector SOL-XE. Measurement conditions: radiation $\mathrm{CoK} \alpha / \mathrm{Fe}$ filter, voltage $40 \mathrm{kV}$, current $40 \mathrm{~mA}$, step of $0.0142 \Theta$, step time $1.25 \mathrm{~s}$ (the sum of five measurements with a step of $0.25 \mathrm{~s}$ ) and digital processing of the resulting data. For the measurement and calculation, the Bruker Diffrac Suite software was used.

The rock samples were also observed with scanning electron microscope FEI Quanta-650 FEG, equipped with energy-dispersive analyzer (EDX)-EDAX Galaxy.

Standard water absorption test was performed for comparison with thermogravimetric (TG/DTG) experiment results. It was impossible, however, to obtain standard cubic samples, as the rock pieces were comparatively small, mostly taken from drill core. Moreover, examined rocks are of slate structure, which is prone to splitting into plates. The lump samples of mass from 20 to $60 \mathrm{~g}$ were dried in the oven to $100{ }^{\circ} \mathrm{C}$ for $45 \mathrm{~min}$. After cooling in desiccators, the samples were soaked in water for $24 \mathrm{~h}$. After this time, the samples were weighed and the mass differences before and after water soaking were determined.

Thermal analysis was performed in Laboratory of Geochemical Engineering (Institute for Applied Geology), with NETZSCH STA 449 F3 Jupiter $^{\circledR}$ equipment, and divided into two parts. Part I was intended to mineral composition examination with the use of TG/DSC methods. The analysis of the rock samples was carried out over the temperature range of $40-1000{ }^{\circ} \mathrm{C}$, under synthetic air atmosphere, with gas flow rate of $50 \mathrm{~mL} \mathrm{~min}^{-1}$. Measurement heating rate was $10 \mathrm{~K} \mathrm{~min}^{-1}$. Rock samples were powdered and put into the alumina $\left(\mathrm{Al}_{2} \mathrm{O}_{3}\right)$ crucible in amount of about $20 \mathrm{mg}$. The curves were interpreted with the help of works of Wyrwicki [12] and Földvári [13]. Part II included TG analysis of lump samples (of about $50 \mathrm{mg}$ ), shaped to fit the STA crucible. The analyses were accomplished in four stages: 1-fresh sample, in air-dry conditions, 2-pure (distilled) water saturated, 3-the same sample saturated with fracturing fluid and 4-fresh samples saturated with fracturing fluid. In each case the saturation was carried out for $24 \mathrm{~h}$. TG analysis was executed in the temperature range of $40-300{ }^{\circ} \mathrm{C}$, under synthetic air atmosphere, in open crucibles (without lids). The

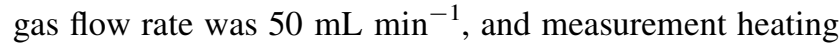
rate $5 \mathrm{~K} \mathrm{~min}^{-1}$.

The fracturing fluid used in the experiments was a fluid prepared for hydraulic fracturing of shale formation and consisted primarily of water (about 99\%) and specific additives:

- viscosity breaker $\left(0.5 \mathrm{~mL} \mathrm{~L}^{-1}\right)$,

- antibacterial agent $\left(0.125 \mathrm{~mL} \mathrm{~L}^{-1}\right)$,

- $\operatorname{surfactant}\left(2 \mathrm{~mL} \mathrm{~L}^{-1}\right)$, 
Table 1 Mineral composition of the rock samples

\begin{tabular}{|c|c|c|c|c|c|}
\hline \multirow[t]{2}{*}{ Sample } & \multirow[t]{2}{*}{ Locality/borehole } & \multirow[t]{2}{*}{ SEM/EDS } & \multicolumn{3}{|c|}{ Analytical method } \\
\hline & & & XRD & mass $\%$ & TG/DSC \\
\hline \multicolumn{6}{|c|}{ Baltic basin } \\
\hline \multirow[t]{6}{*}{ B-1 } & Borcz & Quartz & Quartz & 33.24 & Clay minerals \\
\hline & & Muscovite & Muscovite & 47.05 & Pyrite \\
\hline & & Illite & Chlorite & 6.74 & \\
\hline & & Chlorite & Albite & 6.44 & \\
\hline & & Gypsum & Calcite & 4.59 & \\
\hline & & & Pyrite & 1.89 & \\
\hline \multirow[t]{8}{*}{ B-2 } & Busówno & Quartz Muscovite & Quartz & 36.06 & Clay minerals \\
\hline & & Calcite & Muscovite & 26.30 & Calcite \\
\hline & & & Illite & 9.81 & Pyrite \\
\hline & & & Kaolinite & 2.35 & \\
\hline & & & Albite & 13.76 & \\
\hline & & & Dolomite & 2.34 & \\
\hline & & & Calcite & 6.22 & \\
\hline & & & Pyrite & 3.16 & \\
\hline \multirow[t]{5}{*}{$\mathrm{N}-1$} & Niestępowo & Quartz & Quartz & 31.17 & Illite \\
\hline & & Muscovite & Muscovite & 26.37 & Calcite \\
\hline & & Chlorite & Chlorite & 21.81 & \\
\hline & & & Albite & 6.10 & \\
\hline & & & Calcite & 14.55 & \\
\hline \multirow[t]{8}{*}{ L-1 } & Lithuania $^{\mathrm{a}}$ & & Quartz & 38.11 & Clay minerals \\
\hline & & & Muscovite & 26.45 & Chlorite \\
\hline & & & Chlorite & 13.89 & Pyrite \\
\hline & & & Albite & 5.19 & \\
\hline & & & Orthoclase & 7.89 & \\
\hline & & & Dolomite & 1.25 & \\
\hline & & & Calcite & 5.17 & \\
\hline & & & Pyrite & 2.04 & \\
\hline \multirow[t]{8}{*}{ L-2 } & Lithuania $^{\mathrm{a}}$ & & Quartz & 27.90 & Calcite \\
\hline & & & Muscovite & 22.46 & Pyrite \\
\hline & & & Chlorite & 11.88 & Clay minerals \\
\hline & & & Albite & 6.85 & \\
\hline & & & Orthoclase & 4.58 & \\
\hline & & & Ankerite & 7.08 & \\
\hline & & & Calcite & 17.05 & \\
\hline & & & Pyrite & 2.21 & \\
\hline \multirow[t]{6}{*}{ P-1 } & Prabuty & Calcite & Quartz & 3.23 & Calcite \\
\hline & & & Muscovite & 0.59 & \\
\hline & & & Chlorite & 0.17 & \\
\hline & & & Dolomite & 2.08 & \\
\hline & & & Calcite & 92.61 & \\
\hline & & & Pyrite & 1.33 & \\
\hline \multirow[t]{5}{*}{ W-1 } & Wysin & Quartz & Quartz & 37.67 & Calcite \\
\hline & & Muscovite & Muscovite & 22.56 & Clay minerals \\
\hline & & Orthoclase & Chlorite & 8.69 & Pyrite \\
\hline & & Calcite & Albite & 8.41 & \\
\hline & & Chlorite & Orthoclase & 4.49 & \\
\hline
\end{tabular}


Table 1 continued

\begin{tabular}{|c|c|c|c|c|c|}
\hline \multirow[t]{2}{*}{ Sample } & \multirow[t]{2}{*}{ Locality/borehole } & \multirow[t]{2}{*}{ SEM/EDS } & \multicolumn{3}{|c|}{ Analytical method } \\
\hline & & & XRD & $\operatorname{mass} \%$ & TG/DSC \\
\hline & & Dolomite & Dolomite & 6.48 & \\
\hline & & Gypsum & Calcite & 6.08 & \\
\hline & & & Pyrite & 5.61 & \\
\hline \multicolumn{6}{|c|}{ Mikulov formation } \\
\hline \multirow[t]{8}{*}{ K-1 } & Kobyli & Quartz & Quartz & 15.82 & Clay minerals \\
\hline & & Calcite & Illite & 25.62 & Calcite \\
\hline & & Clay minerals & Kaolinite & 5.49 & \\
\hline & & & Albite & 1.20 & \\
\hline & & & Dolomite & 4.59 & \\
\hline & & & Siderite & 1.88 & \\
\hline & & & Calcite & 44.50 & \\
\hline & & & Pyrite & 0.9 & \\
\hline \multirow[t]{8}{*}{ NM } & Nowe Mlyny & Calcite & Quartz & 18.08 & Calcite \\
\hline & & Quartz & Muscovite & 19.30 & \\
\hline & & Feldspars & Kaolinite & 3.66 & \\
\hline & & & Albite & 3.10 & \\
\hline & & & Dolomite & 2.66 & \\
\hline & & & Siderite & 1.22 & \\
\hline & & & Calcite & 51.39 & \\
\hline & & & Pyrite & 0.48 & \\
\hline \multirow[t]{7}{*}{ N-2 } & Nemcičky & Calcite & Quartz & 25.16 & Calcite \\
\hline & & Quartz & Muscovite & 10.95 & \\
\hline & & & Chlorite & 3.72 & \\
\hline & & & Albite & 2.69 & \\
\hline & & & Dolomite & 4.03 & \\
\hline & & & Calcite & 52.58 & \\
\hline & & & Pyrite & 0.87 & \\
\hline \multirow[t]{7}{*}{ M-1 } & Morkuvky & Calcite & Quartz & 27.73 & Calcite \\
\hline & & Quartz & Muscovite & 8.64 & Clay minerals \\
\hline & & Illite & Chlorite & 4.69 & \\
\hline & & Chlorite & Albite & 1.78 & \\
\hline & & & Dolomite & 6.45 & \\
\hline & & & Calcite & 50.15 & \\
\hline & & & Pyrite & 0.56 & \\
\hline
\end{tabular}

${ }^{\mathrm{a}}$ Names of the boreholes are restricted

- foamer $\left(3 \mathrm{~mL} \mathrm{~L}^{-1}\right)$,

- clay swelling inhibitor $\left(2 \mathrm{~mL} \mathrm{~L}^{-1}\right)$,

- scale inhibitor $\left(1 \mathrm{~mL} \mathrm{~L}^{-1}\right)$.

\section{Rocks samples}

The analysed samples, collected from deep boreholes from Poland. Lithuania and Czechia, represent fine-grained rocks, including siltstones, shales and marls.
Polish and Lithuanian samples B-1, B-2, N-1, L-1, L-2, $\mathrm{P}-1$ and $\mathrm{W}-1$ are lower Silurian shales and siltstones, dark grey in colour. They were collected from boreholes (from depth of about $3000 \mathrm{~m}$ ), in the area of Baltic Basin. Baltic Basin extends from Northern Poland to Lithuania, and it is one of the most interesting areas in Europe in terms of shale gas exploration. The significant unconventional gas and oil resources are accumulated in laterally extensive, organic rich source rocks. The analysed rocks of Baltic Basin are mostly composed of quartz, muscovite and clay minerals (Table 1, Fig. 1). Sample from Niestępowo (N-1) 


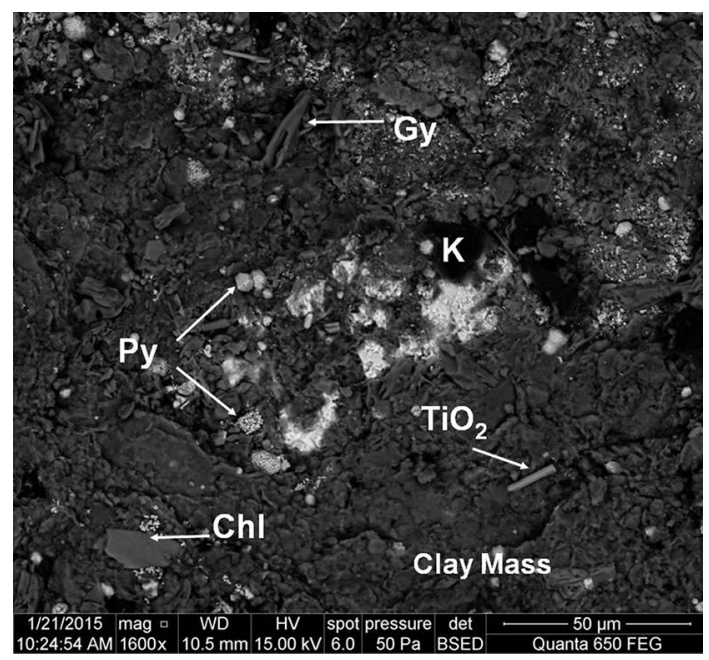

Fig. 1 SEM image of sample B-1. Gy gypsum, Chl chlorite, $K$ kerogen, $P y$ pyrite; clay mass-(chlorite, illite, biotite), $\mathrm{TiO}_{2}-$ rutile

exhibits different mineral composition, as it is a chloriterich shale-the chlorites present are Fe-clinochlore and chamosite. The sample from Busówno (B-2) contains some amount of calcite, apart from quartz and muscovite. Sample from Prabuty (P-1) represents limestone.

Rocks from Czech Republic are represented by samples $\mathrm{K}-1, \mathrm{NM}, \mathrm{N}-2$ and $\mathrm{M}-1$. They are classified as marls, however, rich in organic matter and, in consequence, dark in colour. These samples were collected from boreholes (also from the depth of over $3000 \mathrm{~m}$ ), from the formation of Upper Jurassic Mikulov Marls [14]. This formation is built of 1400-m-thick organic rich rocks, which sourced oils in the Vienna Basin in Czech Republic and Austria [15]. The main minerals forming sampled rocks are calcite and clay minerals, with minor amount of quartz, muscovite and feldspars (Fig. 2). In case of sample from Morkuvky borehole (M-1), some chlorites (chamosite) were stated.

The results of rocks examination analysis are shown in Table 1. The mineral composition determined with the use of a range of methods (provided in the above paragraph) differs, depending on the measurement method. Thermoanalytical methods are believed in general of a little use for determining the mineral composition of argillaceous rocks. Difficulties in interpretation arise from the chemical composition and crystalline structure of clay minerals, the relatively small mass and enthalpy changes involved, the presence of other components such as sulphides and organic material which oxidise during heating $[16,17]$. Nevertheless, thermal methods are used traditionally as complementary ones in case of sedimentary rocks examination [18], as they provide data on clay minerals and organic matter content, which is difficult to obtain by $\mathrm{X}$-ray methods [19].

Figure 3 presents the examples of TG/DSC curves for samples B-2 and N-2, as a result of Part I of thermal experiments.

In the diagram for sample B-2 (Busówno) (Fig. 3a), the dehydration of clay minerals is visible in the range from 40 to $270{ }^{\circ} \mathrm{C}$ (mass loss-0.69\%). In the range of
Fig. 2 XRD pattern of sample NM

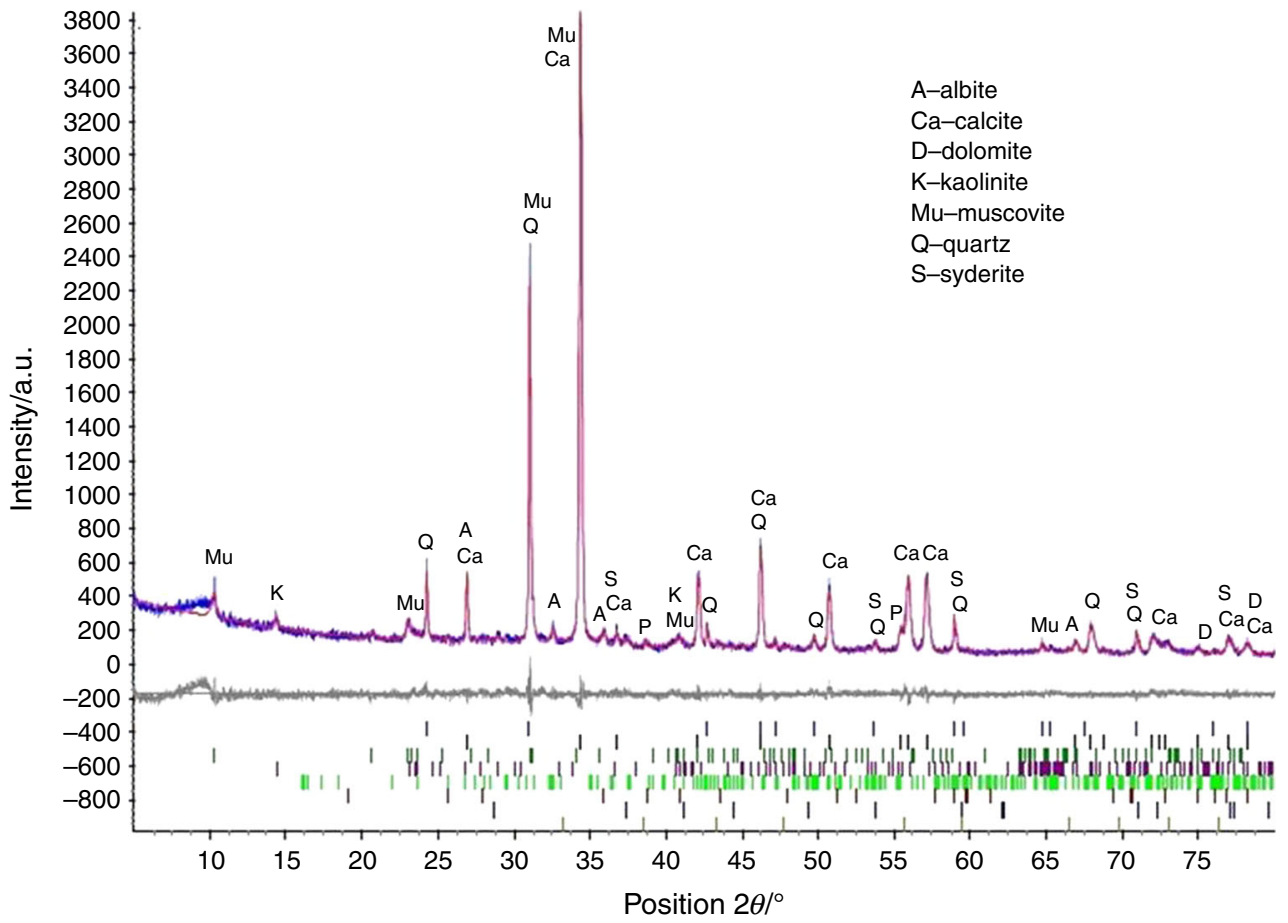


Fig. 3 Example of DSC and TG curves for samples B-2 (a) and $\mathrm{N}-2(\mathbf{b})$
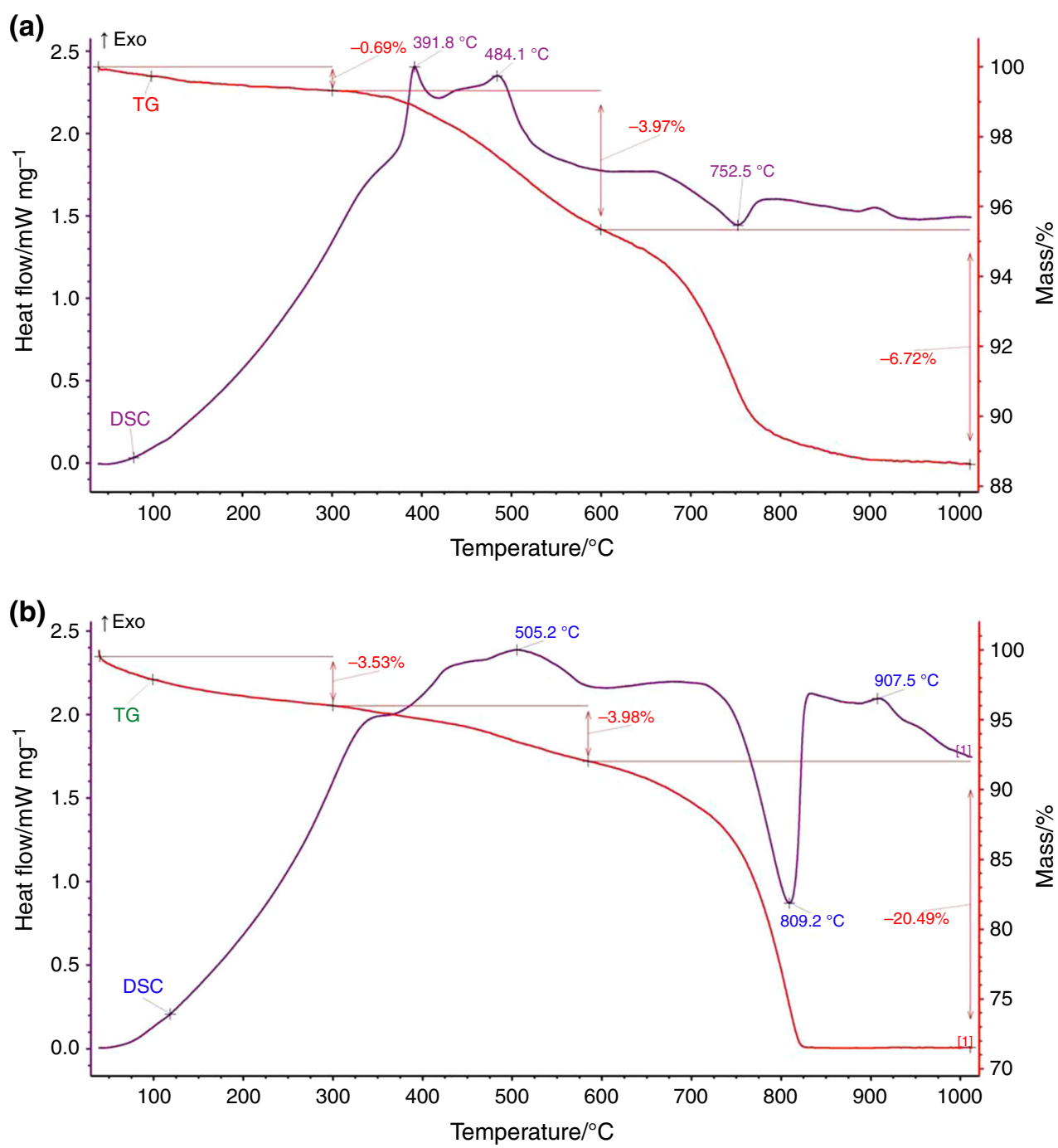

270-600 ${ }^{\circ} \mathrm{C}$, exothermic reactions overlap, resulting in a total loss of sample mass of $3.97 \%$. Combustion of organic matter gives exotherm with a maximum of approx. $392{ }^{\circ} \mathrm{C}$. Successive exotherm, with maximum at $484{ }^{\circ} \mathrm{C}$, is related to the decomposition of pyrite, present in the sample. Between 600 and $800{ }^{\circ} \mathrm{C}$, a significant mass loss $(6.72 \%)$ is observed, which can be interpreted as calcite degradation.

In case of sample N-2 (Nemcičky) (Fig. 3b) in the temperature range from 40 to $280{ }^{\circ} \mathrm{C}$, the process of clay minerals dehydration takes place, connected to loss in mass of $3.53 \%$. The dome exotherm, with a maximum at $505{ }^{\circ} \mathrm{C}$, is associated with the combustion of organic matter, resulting in a loss in the sample mass of $3.98 \%$. The endothermic reaction, clearly visible on the DSC curve, in the temperature range of $600-840{ }^{\circ} \mathrm{C}$, is the effect of calcite degradation. This is accompanied by a significant mass loss of $20.49 \%$. The last exothermic peak $\left(907.5^{\circ} \mathrm{C}\right)$ is derived from spinel phase crystallization.

\section{Water and fracturing fluid absorption measurements}

As it was described above, during Part II of thermal analysis the rock's samples were analysed in four stages and marked accordingly:

0- blank test—fresh sample, in air-dry conditions, Wdistilled water saturated,F-the same sample saturated with fracturing fluid,F2 - fresh samples saturated with fracturing fluid.

The results of the measurements are provided in Table 2 and compared to the results of standard water absorption method (A) (Fig. 4).

The example of the results obtained for each sample from TG measurement is given in Fig. 5. In case of the sample K-1 (Kobyli), 1.27\% loss of mass (stage 0) is a result of yielding hydration water of clay minerals, which are present in the rock (essential water). The same sample, after soaking in distilled water, during the test losses $7.80 \%$ 
Table 2 Results of water and fracturing fluid absorption measurements—mass loss [\%]

\begin{tabular}{lllllll}
\hline Sample & Standard method & \multicolumn{2}{l}{ TG results } & \\
\cline { 3 - 5 } & A & \multicolumn{2}{l}{ Measurement stage } & Real fluid absorption \\
\cline { 3 - 5 } & & 0 & $\mathrm{~W}$ & $\mathrm{~F}$ & $\mathrm{~F} 2$ & F2-0 \\
\hline B-1 & 2.30 & 1.35 & 4.34 & 4.71 & 3.49 & 2.14 \\
$\mathrm{~B}-2$ & 1.55 & 0.63 & 1.81 & 1.43 & 1.70 & 1.07 \\
N-1 & n.o. & 0.98 & 2.72 & 3.49 & 2.14 & 1.16 \\
L-1 & 0.99 & 1.70 & 2.15 & 3.25 & 2.60 & 0.90 \\
L-2 & 2.43 & 1.22 & 3.26 & 3.58 & 3.00 & 1.78 \\
P-1 & 0.35 & 0.15 & 0.22 & 0.47 & 0.21 & 0.06 \\
W-1 & 1.68 & 1.17 & 3.20 & 3.98 & 2.30 & 1.13 \\
K-1 & 5.30 & 1.27 & 7.80 & 6.62 & 6.02 & 4.75 \\
NM & 3.62 & 1.19 & 4.68 & 7.86 & 3.71 & 2.52 \\
N-2 & n.o. & 0.92 & 4.29 & 4.06 & 4.40 & 3.48 \\
M-1 & 1.96 & 0.94 & 2.09 & 2.85 & 3.05 & 2.11 \\
\hline
\end{tabular}

n.o. results not obtained - the samples were destroyed

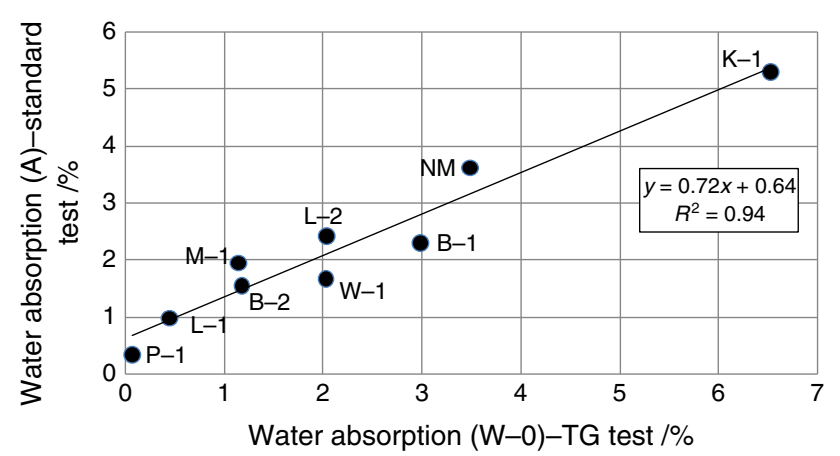

Fig. 4 Correlation of water absorption measured with standard method (A) and TG method (W-0)

Fig. 5 Mass loss [\%] after heating up to $300{ }^{\circ} \mathrm{C}$ for sample $\mathrm{K}-1$ (TG analysis) of mass; and this value could be assumed to represent water absorption capacity of the rock. This sample is very rich in clay minerals (illite, kaolinite); hence, the absorption includes imbibitions into the clay minerals structure. The real water absorption into the rock could be calculated as the difference between the result of stage "W" of the experiment and hydration water (result of stage 0), which in this example equals $6.53 \%$. Consequently, the "real" fracturing fluid absorption could be calculated as a result of subtraction of measurement result in stage " 0 " from "F2"- given in the last column of Table 2.

When the same sample is soaked in fracturing fluid (stage F), the measured absorption is lower (in case of sample K-1 it is $6.62 \%$ ). It should be noted, however, that,

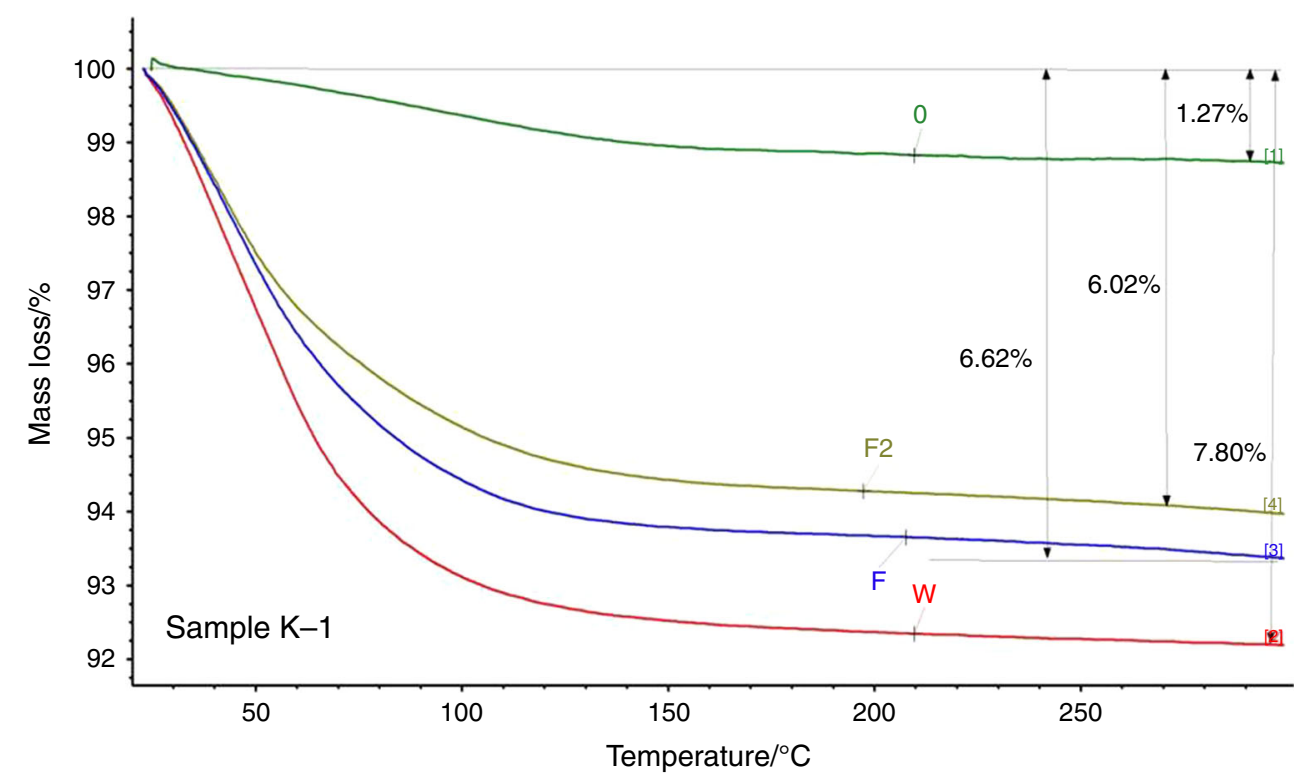




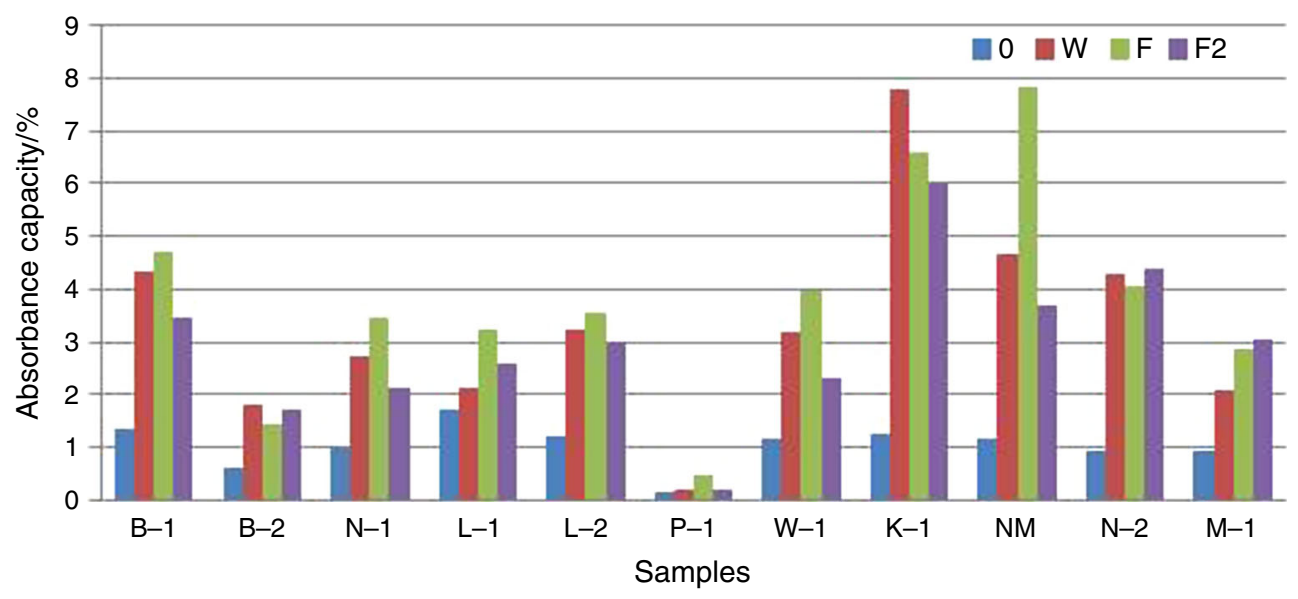

Fig. 6 Comparison of absorbance capacity of the examined samples. Explanations: 0—blank test—fresh sample, W—distilled water saturated, F-the same sample saturated with fracturing fluid, F2 - fresh sample saturated with fracturing fluid

especially in case of shale rocks, which are fissile in fabric, the former water saturation (W) is able to disturb the original rock structure. On the other hand, the fresh samples, which were soaked in fracturing fluid, have lower fluid absorbance capacity (in case of sample K-1-6.02\%).

The comparison of the obtained results from the absorption experiment is provided in Fig. 6. As it is visible from the graph, the most distinctive is the sample P-1, due to very low values of absorbance capacity. The mass loss in case of dry sample (stage 0) is close to $0 \%$ (Table 2), which is the evidence of the absence of clay minerals in the rock, as confirmed by SEM analysis (Fig. 7). Sample P-1 is a limestone, composed of calcite, in which grains are tightly packed. According to TG/DSC analysis, the amount of calcite was calculated to be about $92 \%$. The lack of clay minerals is a primary cause for very low values of water absorbance capacity $(0.22 \%)$ and real fracturing fluid absorbance capacity $(0.06 \%)$.

The other rocks absorb fracturing fluid in amounts from 0.90 to $4.75 \%$. The highest values of fracturing fluid absorbance (over $3.40 \%$ ) revealed marl samples K-1 and $\mathrm{N}-2$. As it can be noticed from Fig. 6, the initial content of clay minerals, which is demonstrated by mass loss of fresh sample (stage 0), is not the crucial parameter in determination of the absorbance of the rocks.

On the basis of observation of the morphology of the rocks by SEM, it can be stated that the structure of the rock and the presence of intergranular spaces are important for the fluid absorption in the studied rocks.

It should be noted here that the results obtained from thermogravimetric analysis are generally consistent with standard water absorption tests. When we compare water absorption (A) from standard measurement and "real" absorption calculated from TG measurement as "W-0" value, the significant correlation is visible (Fig. 4). Obviously, the geometry and size of the sample are very

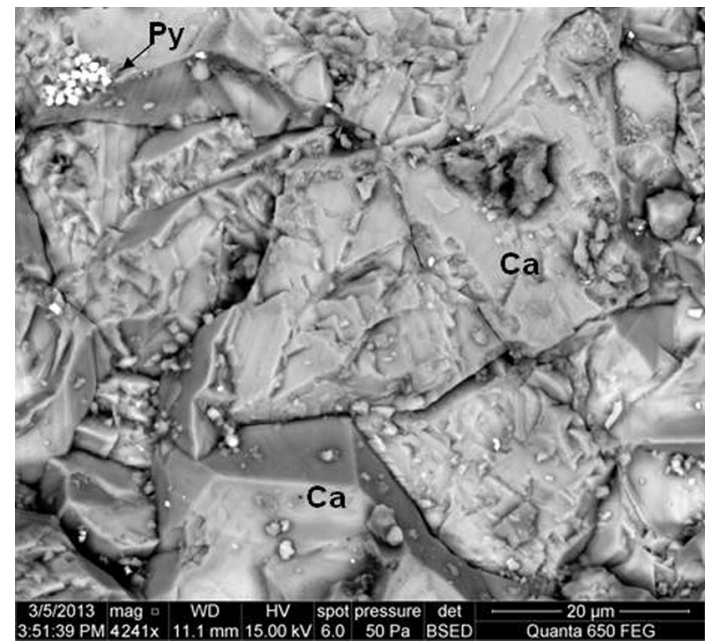

Fig. 7 SEM image of sample P-1 ( $C a$ calcite, $P y$ pyrite)

important, and this is the reason of average higher values of water absorption for small samples used in TG experiment in comparison with much more bigger lump samples used in standard test.

\section{Conclusions}

TG method was proved to be an appropriate tool for measuring water and fracturing fluid absorbance in the rocks. This method enables the measurement on very small (of about $50 \mathrm{mg}$ ) samples, in case the rock sample size is insufficient (which is common in case of samples from deep wells) to carry out the standard water (or other fluid) absorption test.

Water absorption capacity in examined rocks ranges from 0.07 to $6.53 \%$. In case of most of the rocks, this value falls below $5 \%$, which is regarded as low water absorption. 
Only one sample of marl (K-1) from Mikulov formation reveals high water absorption, reflecting high clay minerals content.

Fracturing fluid absorption is in the range of 0.06 to $4.75 \%$. The highest values were recorded for marls samples; in some cases fracturing fluid absorption capacity was even higher than water absorption. This phenomenon indicates that the used fluid is not suitable for fracturing clay-carbonate rocks (marls).

High fluid absorption is related to the presence of minerals of micaceous habit (e.g., muscovite, chlorite) and clay minerals. These phyllosilicates contribute layered structure of shale rocks and are partially responsible for the fate of fracturing fluid.

Acknowledgements The research leading to these results has received funding from the Polish-Norwegian Research Programme, operated by the National Centre for Research and Development under the Norwegian Financial Mechanism 2009-2014, in the frame of Project Contract No Pol-Nor/196923/49/2013.

Open Access This article is distributed under the terms of the Creative Commons Attribution 4.0 International License (http://crea tivecommons.org/licenses/by/4.0/), which permits unrestricted use, distribution, and reproduction in any medium, provided you give appropriate credit to the original author(s) and the source, provide a link to the Creative Commons license, and indicate if changes were made.

\section{References}

1. Kreipl MP, Kreipl AT. Hydraulic fracturing fluids and their environmental impact: then, today, and tomorrow. Environ Earth Sci. 2017;76:160. https://doi.org/10.1007/s12665-017-6480-5.

2. Corrêa CC, Nascimneto RSV. Study of shale-fluid interactions using thermogravimetry. J Therm Anal Calorim. 2005;79:295-8.

3. Siegesmund S, Snethlage R. Stone in architecture: properties, durability. 4th ed. Berlin: Springer; 2010.

4. BS EN 13755:2008 Natural stone test methods. Determination of water absorption at atmospheric pressure.
5. Feng X, Hudson JA, Tan F, editors. Rock characterisation, modelling and engineering design methods. 1st ed. Boca Raton: CRC Press; 2013.

6. Aughenbaugh NB. Effects of humidity on ground control in mining and tunneling. In: Proceedings of the rock mechanics effects of moisture on ground control in mining and tunneling. Mini symposium no 81. Soc Min Eng AIME, 1981. p. 15-20.

7. Farrokhrouz M, Asef MR. Shale engineering: mechanics and mechanisms. 1st ed. Boca Raton: CRC Press; 2013.

8. Zolfaghari A, Dehghanpour H, Noel M, Bearinger D. Laboratory and field analysis of flowback water from gas shales. J Unconv Oil Gas Resour. 2016;14:113-27.

9. Zolfaghari A, Dehghanpour H, Holyk J. Water sorption behaviour of gas shales: I. Role of clays. Int J Coal Geol. 2017;179:130-8.

10. Ge HK, Yang L, Shen YH, Ren K, Meng F-B, Ji WM, Wu S. Experimental investigation of shale imbibitions capacity and the factors influencing loss of hydraulic fracturing fluids. Petrol Sci. 2015;12:636-50.

11. Singh H. A critical review of water uptake by shales. J Nat Gas Sci Engs. 2016;34:751-66.

12. Wyrwicki R. Analiza derywatograficzna skał ilastych. Warszawa: Wyd. UW; 1988.

13. Földvári M. Handbook of thermogravimetric system of minerals and its use in geological practice. Occasional papers of the Geological Institute of Hungary. 2011; p. 213.

14. Panova O, Pryvalov V, Bujok P, Labus K. How deep is the unconventional resource play in Jurassic Mikulov Marls beneath the Czech part of the Vienna Basin?. 79th EAGE conference and exhibition, 12-15 June 2017, Paris. doi: https://doi.org/10.3997/ 2214-4609.201701269.

15. Adamek J. The Jurassic floor of the Bohemian Massif in Moravia-geology and paleogeography. Bull Geosci. 2005;80:291-305.

16. Paulik F, Paulik J, Arnold M, Inczédy J, Kristòf J, LangierKuźniarowa A. Simultaneous TG, DTG, DTA and EGA examination of argillaceous rocks. Part I J Therm Anal. 1989;35:1849-60.

17. Langier-Kuźniarowa A, Inczédy J, Kristòf J, Paulik F, Paulik J, Arnold M, Simultaneous TG. DTG, DTA and EGA examination of argillaceous rocks. Part II. J Therm Anal. 1989;36:67-84.

18. Hagemann F. On the petrography of the Silurian shales from Hadeland, Norway. Norsk Geologisk Tidskrift. 1957;37:229-46.

19. Labus M. Thermal methods implementation in analysis of finegrained rocks containing organic matter. $\mathrm{J}$ Therm Anal Calorim. 2017;129:965-73. 